\title{
Fetal Akinesia Deformation Sequence
}

National Cancer Institute

\section{Source}

National Cancer Institute. Fetal Akinesia Deformation Sequence. NCI Thesaurus. Code C129071.

A condition characterized by fetal akinesia and intrauterine growth restriction, that may be associated with mutation(s) in the RAPSN or DOK7 genes, encoding $43 \mathrm{kDa}$ receptorassociated protein of the synapse and protein Dok-7, respectively. 